\title{
Microzonation of ground dominant periods at city of Ensenada, Baja California
}

Microzonación de Periodos Dominantes del suelo la ciudad de Ensenada, Baja California

\author{
Gema Ibarra-Torúa (Main and Contact Author) \\ Universidad Autónoma de Baja California \\ Instituto de Ingeniería/MYDCl
}

+52(662)259 2183

Blvd. Rodríguez y Rosales, Col. Centro C.P. 83000

Hermosillo, Sonora, México

gema.ibarra@uabc.edu.mx

\author{
José Acosta-Chang \\ Centro de Investigación Científica y de Educación \\ Superior de Ensenada. \\ jchang@cicese.mx
}

\author{
Leobardo López-Pineda \\ Universidad Estatal de Sonora \\ leobardo.lopezpineda@gmail.com
}

\begin{abstract}
Resumen
Las estructuras civiles son mayormente dañadas cuando el período fundamental de la estructura es cercano al período dominante (PD) del movimiento del suelo donde se encuentra cimentada. Para mejorar la seguridad de diseños antisísmicos de estructuras civiles nuevas o de reforzamientos de estructuras existentes, es de vital importancia la creación de mapas de microzonación del período dominante, donde se comprendan las manchas urbanas y aquellas áreas con altas posibilidades de desarrollo urbano futuro. En este trabajo se plasma un mapa con la distribución de PD del suelo en la ciudad de Ensenada, B.C., México, utilizando el método de cocientes espectrales a partir de vibración ambiental, obteniendo resultados confiables, ya sea por la distribución de la litología, así como el de estudios previos realizados en otras zonas, ya que los valores presentados se encuentran dentro de los rangos que se publican en otros trabajos en diferentes zonas del mundo. Es importante señalar que este trabajo forma parte de un proyecto, en el cual se midieron PD en cuatro centros urbanos del Estado de Baja California, México.
\end{abstract}

Palabras clave: Microzonación sísmica; respuesta de sitio; periodo dominante, cocientes espectrales, Nakamura.

\section{INTRODUCTION}

The strongest earthquakes in memory of individuals are undoubtedly are those who have thrown more human and material losses. Among recent experiences in the past are: Japan 2011, Italy 2012, Chile and Haití in 2010. In these and other events, the importance of the effect on the production site of tragic damage associated with earthquakes is confirmed. The movement on the ground surface at a given with soft soils or weathered site may differ radically from that taken into rock, by alterations of seismic waves due to geological, topographic and subsurface stiffness effects.

The site effect is the result of procedures of deposition, weathering, erosion and other geological processes which generate strong differences in physical properties of the relatively small surface structures (Aki, 1988); for this, the last meters of travel seismic waves become important in the formation of ground motion. The soil response to the arrival of a seismic wave is determined by the type of incident waves, the

\section{Abstract}

The civil structures are mostly damaged when the fundamental period of the structure is close to the dominant period of ground motion (DP) where it is founded. To increase the security of the seismic design of new structures or the reinforcement of existing structures, it is essential to develop microzonation maps of the dominant period, where urban spots and areas with high potential for future urban development will contain.

We presented a map with the distribution of DP of soils in the city of Ensenada, Baja California, México, using the method of spectral ratios with ambient vibration, obtaining consistent results, either by the distribution of lithology and like previous studies in other areas, as presented values are within the ranges published in other works in different areas at world. Importantly, this work is part of a project, in which DP were measured in four urban centers of the state of Baja California, México.

Keywords: Seismic microzonation; site response; dominant period, spectral ratios, Nakamura.

direction in which they reach the surface as well as the consistency of the field where act. One component of site effect is the dominant period of ground motion (DP), which can be defined as the period (seconds) of the harmonica with greater amplitude of ground motion. Its value depends on the physical and geometrical characteristics of the shallow stratigraphy. This is a derivative of the spectral content of the seismic records parameter.

The civil structures are damaged more by earthquakes when the fundamental period of vibration of the structure is similar to the dominant period of ground motion where it is foundation on. The essential characteristics of the response of a simple structure reach estimate with acceptable accuracy to model the structure by a single degree of freedom system, just as the fundamental period of the structure. If several single degree of freedom systems are exposed to different periods, to a history of ground motion, each responds very differently; the amplitude of its response depends essentially on the relationship between the natural period of the structure (NSP), 
and the dominant period of soil motion (DP); (NSP/SP). As illustrated in Figure 1 , if ratio is closer to the unit, then greater the amplitude of the response (Bazán and Meli, 2002).
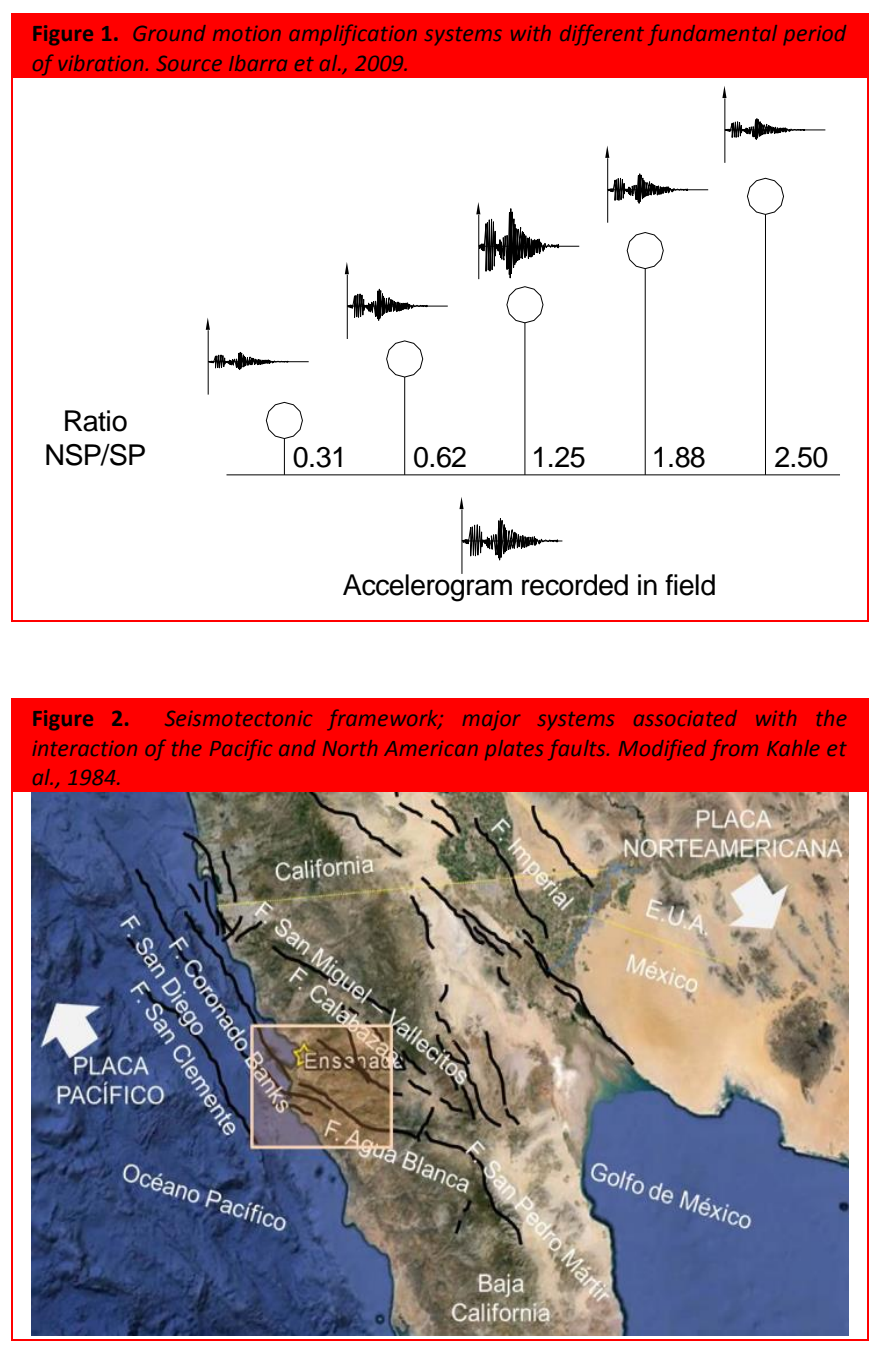

\section{LITERATURE REVIEW}

The long term objective of seismic microzonation of an urban area involves creating various types of maps, with the distributions of the different parameters of interest in the earthquake engineering, such as maps of acceleration, maximum velocities of soil, of seismic intensities, maximum response spectra and dominant periods of ground motion values. Different authors in the world have been working on microzonation maps that will request to incorporate into building regulations. (Gallipoli et al. 2004-Claudet Bonnefoy, S. et al. 2009). Acosta et al. (1994), initiated a study of seismic microzonation at Tijuana, México area, based on the distribution of dominant periods; they apply the method of Nakamura (1989) that relates the horizontal and vertical components of ground motion. In Ensenada, México there is a preliminary map of dominant periods of ground motion, presented by Alvarez et al. (1997), in which also the value of the dominant period is estimated from the spectral ratios technique.

\section{Regional tectonic}

Figure 2 shows the tectonic setting of the northern region of Baja California, in which the main active faults are shown. Tectonic activity in this region is correlated with three groups of faults. The first group is in the east of the region as part of the San Andreas Fault system, which can be considered as the most active (Raines et al., 1991) located along the Mexicali-Imperial Valley, including failures active: Imperial, Cerro Prieto, Cucapá, Elsinore, Brawley and Laguna Salada. The second group includes faults related to the main escarpment Gulf: San Pedro Mártir, San Felipe and Sierra Juárez Fault zone. The Sierra Juárez Fault system is particularly active in the central segment with two clusters located at the ends of this segment (Frez and Frias, 1998). In the third group are located to the west: ocean systems failures as Coronado Banks, depressions San Diego and San Clemente Fault (Stock et al., 1991), the first two extend his line to the coast of Ensenada and then continue inland south of the city, including the Agua Blanca (Gastil et al., 1975) fails. Northeast of Ensenada is the San Miguel-Vallecitos-Calabaza Fault system.

The marked area in Figure 2 also shows the city of Ensenada, Baja California, which is located near active faults mentioned above. According to the USGS (United States Geological Survey) is frequent detect earthquakes in this area, most with depths no greater than $10 \mathrm{Km}$, several magnitude $\mathrm{ML}>6$ caused by failures Cerro Prieto, Imperial and San Miguel (Frez and Gonzalez, 1991).

\section{Surface geology}

The importance of the surface geology of the city of Ensenada, México, reference is having different lithological contacts to see if there is a relationship with the values of DP of soil obtained in measurements. Selected sites within the city of Ensenada, México were according to the geological characteristics of soils, supported by geological maps of INEGI (Instituto Nacional de Estadística y Geografía), with scale 1: 50,000 and information was confirmed by visual recognition were identified five types of soils which are described below and shown in Figure 3.

- Bay mud. A narrow strip of this material is located parallel to the coast. This soil is composed of fine sandy beaches that are subject to continuous waves.

- Alluvium. The center of Ensenada is about this type of material. It consists of gravel deposits, clay and poorly consolidated sands; these particles come from the rocky outcrops around.

- Sandstone. Located at north side, exit to the city of Tijuana, Mexico. It consists sandy material mix and poorly consolidated sands.

- $\quad$ Rhyolitic tuff. It is located near the center of the city and extends to the north exit of the same. It is a rounded and angular consolidated rock, with sandy material mix.

- Extrusive igneous rock. IGEA. It is located at the ends of urban area, northeast and southwest of the city.

- Intrusive igneous rock. IGIA. This type of outcrop is located northeast of the city of Ensenada; upon this rock is constructed the Emilio López Zamora curtain dam. 


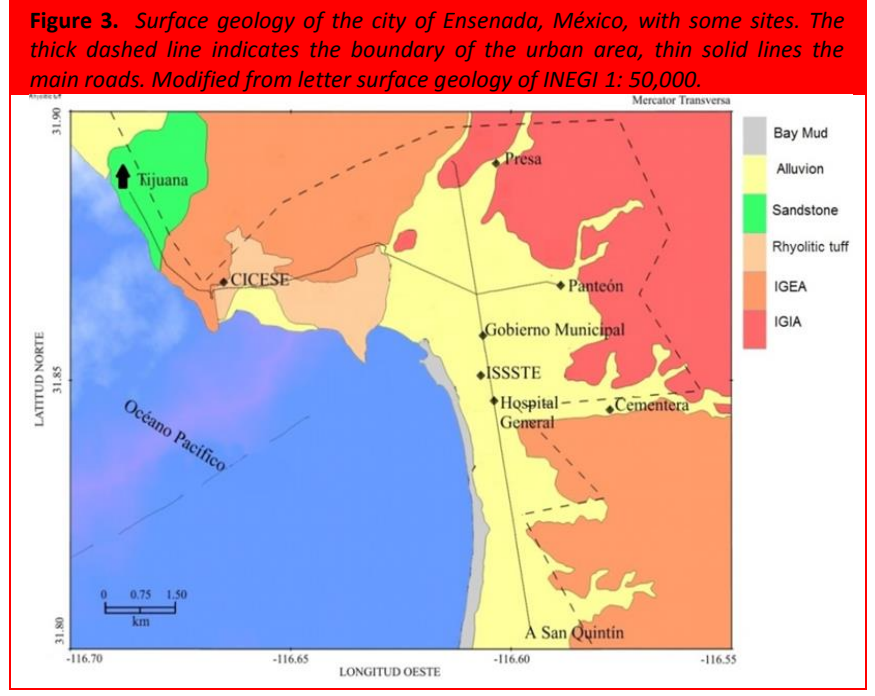

METHOD FOR ESTIMATING THE SITE EFFECT

The estimate site effects from the analysis of empirical data obtained on the ground surface is based on the elimination of the effects of the source and the path and isolating the effects of the shallow lithology in the registration site. The literature states that you can use the ground motion induced by microtremor (seismic ambient noise) to a proper estimation of the dominant period of a site on the surface provided the source and path effects are properly removed.

Kanai (1957) proposed to use measurements of ambient vibration, which is a combination of microseisms and microtremors. The microseisms are globally induced by oceanic and atmospheric activities with periods longer than 4 seconds vibration; while microtremors are movements induced by urban noise of a local nature, during short periods. This author chooses this option, because soils respond equivalently to the sources of noise sources as earthquakes. A common technique for estimating the site effect measurements from microtremors is calculating spectral ratios of the horizontal and vertical components of the ground motion (Nakamura, 1989).

$E=\beta T / 4$

where:

$E=$ thickness of layer

$\beta=$ speed of propagation of the $S$ wave

$\mathrm{T}=$ dominant period of ground motion

$$
C(f)=\frac{H S(f)}{V S(f)}
$$

The analytical approach of the Nakamura's technique is to consider spectra at the surface and at the base of the sedimentary layer, uses four spectra: a horizontal (HS) and vertical (VS) spectrums on the surface; and two more at the base of the sedimentary layer: a horizontal (HB) and vertical (VB) spectrums. The two spectra in depth, although they appear in the analytical development, really are not necessary for the application of the method, as discussed below. Seismic noise measurement of the horizontal component, recorded on the surface of the sediment layer contains natural sources distant effects which propagate as body waves ( $P$ and $S$ ) and local sources such as Rayleigh waves propagates. If the formula by Aki (1988) which relates the thickness of a layer with multi reflected wave length and propagation velocity of this wave is used (Eq. 1).

Can meet the thicknesses of the layers and can be observed by microtremor body waves vertically propagated. The layer thickness which may affect the vertical movement varies from 250 to 1250 meters, considering the periods of engineering interest are between 1 and 5 seconds, the $P$ wave velocity is usually greater than $1000 \mathrm{~m} / \mathrm{s}$.

As the site effects are produced on the waves at the last $30 \mathrm{~m}$ before reaching the surface, and then it is considered that the site effect does not affect the vertical component of seismic noise records. An estimate of the site effect is given by the spectral ratio between the horizontal and vertical components of surface movement.

\section{Data capture}

Velocity records of ground motion were taken by means of ambient noise in dozens of sites within the city of Ensenada, México, trying to cover the different types of surface geology. The sensors used in capturing records are intermediate period, vertical and horizontal seismometers brand Kinemetrics, SV-1 and SH-1 models, the recorders are Kinemetrics model SSR-1.

\section{Data processing}

Once the database, consisting of digital seismograms of ambient noise, it is necessary to apply a series of processes to obtain results that may be relevant and easy to use for professionals in the earthquake engineering. The procedure is:

a) The first part involves the application of a series of numerical processes for transforming time series, until statistically stable Fourier spectra of the ambient noise representation; this is achieved by smoothing methods and averaging the spectral amplitudes.

b) The second part of the procedure aims to isolate, or at least highlight, the local characteristics of ground motion, including the dominant period of the soil. For this, methods of spectral ratios and smoothing are applied.

c) Displaying the value of the dominant period of the ground motion is estimated from graphs of the spectral ratios.

d) A map of microzonation of DP of ground motion for each study area is developed, by means of the distribution of the values obtained in the measurement points.

The values of the dominant soil period obtained in Ensenada are shown in Table 1, followed by a citymap where sensors and dominant period value obtained in each of them also apear (Fig. 4). Geographic distribution of the DP is shown in a DP isovalues map, that shows clearly the variation tendencies of that parameter (Fig 5) 

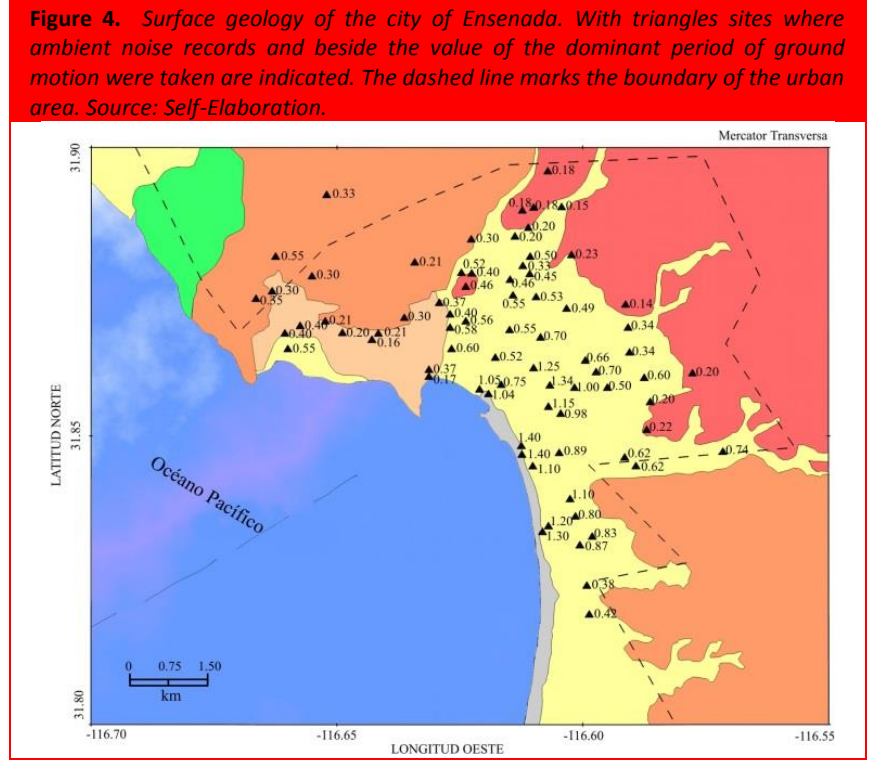

Smaller values of DP of ground motion in the city of Ensenada are associated with rocky outcrops in different areas of the city, ranging from 0.14 to 0.22 seconds on intrusive igneous rock (IGIA) at north and east, from 0.20 to 0.55 seconds on rhyolitic tuff to the west of the city.

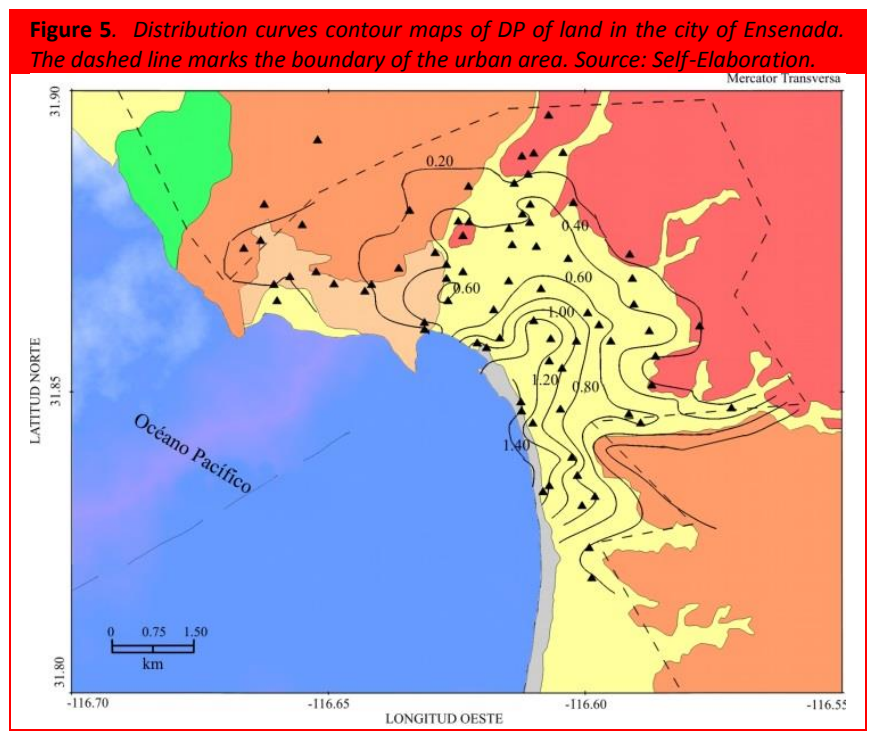

The highest values of DP of ground motion are observed in loose sedimentary soils. As a general trend, a gradual increase from 0.60 to 1.40 seconds from the sediment-rock contact in the east of the city, towards the coast.

The records located on bay mud material, parallel to the coast, shown values from 1.04 to 1.40 seconds, those values being the highest for this city; and is where the greater thicknesses of sediments due to the direction of flow of alluvial material streams that traverse the area from east to west are expected. In alluvial ground, DP of ground motion values ranging from 0.40 to 1.34 seconds.

\section{CONCLUSIONS}

Microzonation map of dominant periods (DP) of ground motion in Ensenada, Baja California, Mexico was obtained. For this we applied the Nakamura's technique of spectral ratios, on triaxial records of ambient noise. The geographical distributions of the values of DP show a good agreement with the surface geology in cities where there is lateral variation thereof also increased DP values approaching the coast can be seen, this behavior may associate the increase in the sediment thickness from east to west.

Using ambient noise for determining the DP of ground motion is a safe and convenient method because it is not necessary to have a basis of earthquake records.

The microzonation map of DP of ground motion presented in this paper is only a small part of a number of jobs characterization seismic effect in main cities at Baja California, México done, and have been done in medium and long term in the region, so as part of this work had already been presented (Ibarra et al., 2009), but for the city of Tijuana, Mexico.

However, the results reflected in the map of Ensenada, México helps to specialists in design of civil structures to perform calculations. So directly that lies in design a structure with a fundamental period far out of values of DP in the area where is planning to build the structure.

It is important to note that the Normas Técnicas Complementarias para Diseño por Sismo (2001) Cd. De México, appear equations that make up the design spectrum based on the expected longer period dominant of soil. The map presented has the limitation that the measurement points were made within the existing urban area at this time, so that in future it will be necessary to develop studies of dominant periods of vibration of the ground in areas where there is a new urban development which lies outside the area covered in this study.

\section{ACKNOWLEDGEMENTS}

The authors of this work manifest thanks CICESE applied seismology laboratory technicians for the support in the work carried out. 


\section{REFERENCES}

Acosta, J., Álvarez S., Mendoza L. \& Arellano G. (1994) Microzonación del área de Tijuana, B. C., con base en la distribución de periodos dominantes del movimiento del suelo. Comunicaciones Académicas. CTSIT9402. Ensenada, México. CICESE.

Aki, K. (1988) Local site effects on strong ground motion. Earthquake engineering and soil dynamics II. Von Thun, J. Lawrence, (Editor) American Society Civil Engineering. Geotechnical Special Publication, 20(1), 103- 155.

Álvarez, S. \& Acosta J. (1997) Microzonación de periodos dominantes del movimiento del suelo en Ensenada, B. C. Comunicaciones Académicas. CTSIT9709. CICESE.

Bazán, E. \& Meli R. (2002) Diseño sísmico de Edificios. Editorial Limusa, S.A. y Noriega Editores. 1st Ed, México D.F.

Bonnefoy-Claudet, S., Baize S., Bonilla L.F., Berge C., Pasten, C., Campos, J., Volant, P. \& Verdugo, R., 2009. Site effect evaluation in the basin of Santiago de Chile using ambient noise measurements, Geophysical Journal International,176(3), 925-937.

Frez, J. \& Frías-Camacho V. M. (1998) Mapas anuales de sismicidad para la región fronteriza de ambas Californias. GEOS, 18(2),112-130.

Gallipoli, M.R., Mucciarelli, M., Castro, R. R., Monachesi, G. \& Contri, P., (2004) Structure, soil-structure response and effects of damage based on observations of horizontal-to-vertical spectral ratios of microtremors, Soil Dynamics And Earthquake Engineering, 24(6), 487-495.

Gastil, R. G., Phillips R. P. \& Allison E. C. (1975). Reconnaissance geology of the state of Baja California, The Geological Society of America, Inc: Colorado.

Ibarra G, (2004) Microzonación de Periodos Dominantes del Suelo de los Principales Centros Urbanos de Baja California. Tesis Magíster en Ciencias de la Tierra. Centro de Investigación y de Estudios Superiores de Ensenada. México [Thesis in Spanish].

Ibarra, G., Oliver, F., \& Acosta, J. (2009) Microzonación de Periodos Dominantes del suelo de la ciudad de Tijuana, Baja California. Epistemus, 7(2), 13-17.

Kanai, K. (1957). The requisite conditions for predominant vibration of ground. Bulletin Earthquake Response. Institute Tokio University, 35(3), 457-470.

Nakamura, Y. (1989). A method for dynamic characteristics estimation of subsurface using microtremor on the ground surface. Quarterly Rept. Railway Tech. Res. Inst. Jap., 30(1), 25-33.

Normas Técnicas Complementarias para Diseño por Sismo: adiciones (2001) Gobierno del Distrito Federal, México.

Raines, G. L., Hatch M.E. \& Haley S. (1991). Liquefaction Potential in the San Diego-Tijuana Metropolitan region. En: Environmental perils San Diego region. Woodward-Clyde Consultants ed., San Diego, Ca.,109-118.

Stock, J. M., Martín A., Suárez F., \& Miller M. (1991) Miocene to Holocene Extensional Tectonics and Volcanic Stratigraphy of NE Baja California, Mexico. En: Walawender M. J. and Hanan B. (Eds.). Geological excursions in Southern California and Mexico. 1991 Annual Meeting Geological Society of America San Diego, California, 44-67. 


\begin{tabular}{|c|c|c|c|c|c|c|c|}
\hline \multicolumn{4}{|c|}{$\begin{array}{l}\text { Table I. Values of DP of ground motion for the city of Ensenada. B.C., México. } \\
\text { Source: Self-Elaboration. }\end{array}$} & \multirow{2}{*}{$\begin{array}{l}39 \\
40\end{array}$} & \multirow{2}{*}{$\begin{array}{r}-116.5870 \\
-116.5915\end{array}$} & \multirow{2}{*}{31.8510} & \multirow{2}{*}{$\begin{array}{l}0.22 \\
0.62\end{array}$} \\
\hline Station & Lonaitude & Latitude & Period & & & & \\
\hline number & West & North & (s) & 41 & -116.6142 & 31.8743 & 0.55 \\
\hline 1 & -116.6665 & 31.8737 & 0.35 & 42 & -116.6429 & 31.8666 & 0.16 \\
\hline 2 & -116.6632 & 31.8750 & 0.30 & 43 & -116.6124 & 31.8467 & 1.40 \\
\hline 3 & -116.6625 & 31.8810 & 0.55 & 44 & -116.6070 & 31.8343 & 1.20 \\
\hline 4 & -116.6521 & 31.8917 & 0.33 & 45 & -116.6070 & 31.8550 & 1.15 \\
\hline 5 & -116.6551 & 31.8776 & 0.30 & 46 & -116.6210 & 31.8580 & 1.05 \\
\hline 6 & -116.6575 & 31.8690 & 0.40 & 47 & -116.5875 & 31.8600 & 0.60 \\
\hline 7 & -116.6524 & 31.8698 & 0.21 & 48 & -116.6178 & 31.8635 & 0.52 \\
\hline 9 & -116.6416 & 31.8677 & 0.21 & 49 & -116.6600 & 31.8650 & 0.55 \\
\hline 10 & -116.6313 & 31.8614 & 0.37 & 50 & -116.6270 & 31.8710 & 0.40 \\
\hline 11 & -116.6292 & 31.8730 & 0.37 & 51 & -116.6227 & 31.8840 & 0.30 \\
\hline 12 & -116.6313 & 31.8602 & 0.17 & 52 & -116.6123 & 31.8890 & 0.18 \\
\hline 13 & -116.6270 & 31.8687 & 0.58 & 53 & -116.6111 & 31.8860 & 0.20 \\
\hline 14 & -116.6238 & 31.8758 & 0.46 & 54 & -116.6107 & 31.8810 & 0.50 \\
\hline 15 & -116.6247 & 31.8782 & 0.52 & 55 & -116.6108 & 31.8780 & 0.45 \\
\hline 16 & -116.6071 & 31.8958 & 0.18 & 56 & -116.6095 & 31.8740 & 0.53 \\
\hline 17 & -116.6100 & 31.8895 & 0.18 & 57 & -116.6086 & 31.8670 & 0.70 \\
\hline 18 & -116.6138 & 31.8845 & 0.20 & 58 & -116.6048 & 31.8470 & 0.89 \\
\hline 19 & -116.6122 & 31.8794 & 0.33 & 59 & -116.6026 & 31.8390 & 1.10 \\
\hline 20 & -116.6148 & 31.8770 & 0.46 & 60 & -116.6015 & 31.8360 & 0.80 \\
\hline 21 & -116.6149 & 31.8683 & 0.55 & 61 & -116.6006 & 31.8310 & 0.87 \\
\hline 22 & -116.6166 & 31.8588 & 0.75 & 62 & -116.5992 & 31.8240 & 0.38 \\
\hline 23 & -116.6192 & 31.8572 & 1.04 & 63 & -116.5987 & 31.8190 & 0.42 \\
\hline 24 & -116.6043 & 31.8896 & 0.15 & 64 & -116.6363 & 31.8704 & 0.30 \\
\hline 25 & -116.6023 & 31.8813 & 0.23 & 65 & -116.5981 & 31.8325 & 0.83 \\
\hline 26 & -116.6033 & 31.8720 & 0.49 & 66 & -116.6606 & 31.8677 & 0.40 \\
\hline 27 & -116.5913 & 31.8727 & 0.14 & 67 & -116.6226 & 31.8781 & 0.40 \\
\hline 28 & -116.5908 & 31.8687 & 0.34 & $\begin{array}{c}\text { Station } \\
\text { number }\end{array}$ & $\begin{array}{c}\text { Longitude } \\
\text { West }\end{array}$ & $\begin{array}{l}\text { Latitude } \\
\text { North }\end{array}$ & $\begin{array}{l}\text { Period } \\
\text { (s) }\end{array}$ \\
\hline 29 & -116.5995 & 31.8630 & 0.66 & 68 & -116.5715 & 31.8472 & 0.74 \\
\hline 30 & -116.6067 & 31.8587 & 1.34 & 69 & -116.6238 & 31.8698 & 0.56 \\
\hline 31 & -116.6125 & 31.8482 & 1.40 & 70 & -116.6342 & 31.8800 & 0.21 \\
\hline 32 & -116.6102 & 31.8447 & 1.10 & 71 & -116.6267 & 31.8650 & 0.60 \\
\hline 33 & -116.6082 & 31.8333 & 1.30 & 72 & -116.6100 & 31.8617 & 1.25 \\
\hline $\begin{array}{c}\text { Station } \\
\text { number }\end{array}$ & $\begin{array}{c}\text { Longitude } \\
\text { West }\end{array}$ & $\begin{array}{l}\text { Latitude } \\
\text { North }\end{array}$ & $\begin{array}{c}\text { Period } \\
(\mathrm{s})\end{array}$ & 73 & -116.6017 & 31.8583 & 1.00 \\
\hline 34 & -116.6045 & 31.8538 & 0.98 & 74 & -116.5950 & 31.8583 & 0.50 \\
\hline 35 & -116.5973 & 31.8610 & 0.70 & 75 & -116.5892 & 31.8447 & 0.62 \\
\hline 36 & -116.5905 & 31.8644 & 0.34 & & & & \\
\hline 37 & -116.5777 & 31.8608 & 0.20 & & & & \\
\hline 38 & -116.5863 & 31.8558 & 0.20 & & & & \\
\hline
\end{tabular}

